\section{Reaction of fibroblasts to various dental casting alloys}

Craig RG, Hanks CT. Reaction of fibroblasts to various dental casting alloys. J Oral Pathol 1988: 17: 341-347.

The cytotoxicity of a series of dental casting alloys in the as-cast and polished condition was determined with cell culture techniques involving phase contrast microscopy to examine cell morphology and the succinic dehydrogenase histochemical reaction to measure any ring of inhibition of Balb/c 3T3 cellular respiration around alloys. Crown and bridge casting alloys and a nickel- and a cobalt-base alloy were biocompatible in the polished condition, but less so in the as-cast condition. The only two exceptions were casting alloys containing $50-60$ wt \% Cu. Porcelain-fused-to-metal alloys were biocompatible in either the as-cast or polished condition. This direct contact method appeared satisfactory for evaluating biocompatibility of dental casting alloys, especially since these materials are in contact with gingival tissues.

\section{R. G. Craig, C. T. Hanks}

School of Dentistry, University of Michigan, Ann Arbor, U.S.A.
Robert G. Craig, Ph.D., Biologic and Materials Sciences, School of Dentistry, The University of Michigan, Ann Arbor, MI 48109-1078, U.S.A.

Accepted for publication August 8, 1988
The present study quantitates the in vitro cytotoxicity of a variety of dental casting alloys using cell culture techniques combined with phase contrast microscopy followed by histochemical staining and optical density determination to assess succinic dehydrogenase activity.

Kawahara et al. (1) used tissue cul- ture methodology to test the cytotoxicity of pure metals and alloys. The cytotoxicity of pure metals to L-cells was related to the periodic table of elements.

Dissolution of elements in dental alloys has been considered essential for cytotoxic response to cells. Bergman and Ginstrup (2) measured the dissolu- tion rate of cadmium from dental gold solders and found it to be $0.04 \mathrm{mg} /$ $\mathrm{yr} / \mathrm{mm}^{2}$ or about $2 \mathrm{mg} / \mathrm{yr}$ for an average area of a soldered joint. The total intake limit for cadmium per year has been set at 21-26 mg. A later paper by Bergman et al. (3) established that in animals the cadmium released accumulated in the liver and kidney.

Table 1. Alloys, manufacturers, batch numbers and approximate compositions

\begin{tabular}{llll}
\hline Alloy & Manufacturer & Batch Number & Composition, wt \% \\
\hline CASTING & & & \\
Firmilay & Pennwalt-Jelenko & 6693001985 & $74.5 \mathrm{Au}, 3.5 \mathrm{Pd}, 11 \mathrm{Ag}, 11 \mathrm{Cu}$ \\
Rajah & Pennwalt-Jelenko & 7645031585 & $58 \mathrm{Au}, 3.5 \mathrm{Pd}, 27 \mathrm{Ag}, 11.5 \mathrm{Cu}$ \\
Midas & Pennwalt-Jelenko & 0222082885 & $46 \mathrm{Au}, 6 \mathrm{Pd}, 39.5 \mathrm{Ag}, 7.5 \mathrm{Cu}, 1 \times$ \\
Forticast* & Pennwalt-Jelenko & 6693001985 & $42 \mathrm{Au}, 9 \mathrm{Pd}, 26 \mathrm{Ag}, 21.5 \mathrm{Cu}, 1.5 \mathrm{Ni}$ \\
Midigold & Williams Gold & 873650070185 & $49.5 \mathrm{Au}, 3.5 \mathrm{Pd}, 35 \mathrm{Ag}, 10 \mathrm{Cu}, 2 \mathrm{In}$ \\
Minigold & Williams Gold & $86715 \mathrm{~B} 091385$ & $40 \mathrm{Au}, 4 \mathrm{Pd}, 47 \mathrm{Ag}, 7.5 \mathrm{Cu}, 1.5 \times$ \\
Satincast* & Jeneric & 04038527 & $26 \mathrm{Au}, 10 \mathrm{Pd}, 48 \mathrm{Cu}, 16 \mathrm{Ag}$ \\
Albacast & Pennwalt-Jelenko & 8703052485 & $25 \mathrm{Pd}, 70 \mathrm{Ag}, 3 \mathrm{In}, 2 \mathrm{Zn}$ \\
MS* & & None & $62 \mathrm{Cu}, 27 \mathrm{Al}, 5 \mathrm{Ni}, 4.5 \mathrm{Fe}, 1.5 \mathrm{Mn}$ \\
& & \\
PORCELAIN-FUSED-TO-METAL & Pennwalt-Jelenko & 8629062485 & $87 \mathrm{Au}, 6 \mathrm{Pd}, 4.5 \mathrm{Pt}, 2 \mathrm{Fe}, \mathrm{In}, \mathrm{Sn}$ \\
Jelenko "O" & Pennwalt-Jelenko & 7371031885 & $52.5 \mathrm{Au}, 27 \mathrm{Pd}, 16 \mathrm{Ag}, 4.5 \times$ \\
Cameogold & Pennwalt-Jelenko & 8987073185 & $51.5 \mathrm{Au}, 38.5 \mathrm{Pd}, 8.5 \mathrm{In}, 1.5 \times$ \\
Olympia & Pennwalt-Jelenko & 8282052985 & $88 \mathrm{Pd}, 5 \mathrm{Co}, 7 \times$ \\
PTM 88 & Williams & $75 \mathrm{Au}, 13 \mathrm{Pd}, 10 \mathrm{Ag}, 2 \times$ \\
Will Ceram Y-1 & Williams & $77685 \mathrm{~A} 092385$ & $54 \mathrm{Au}, 26.5 \mathrm{Pd}, 15.5 \mathrm{Ag}, 4 \times$ \\
Will Ceram W & Williams & $86617 \mathrm{~A} 090985$ & $45 \mathrm{Au}, 40.5 \mathrm{Pd}, 6 \mathrm{Ag}, 8.5 \times$ \\
Will Ceram W-2 & Williams & $86617 \mathrm{~A} 090985$ & $77 \mathrm{Ni}, 12.5 \mathrm{Cr}, 4 \mathrm{Mo}, 1.7 \mathrm{Be}, 4.8 \times$ \\
Will Ceram Litecast B & Dentsply & $80 \mathrm{Ni}, 14 \mathrm{Cr}, 2 \mathrm{Be}, 4 \times$ \\
Biobond II & Jeneric & 07278543 & $76 \mathrm{Ni}, 13 \mathrm{Cr}, 5.5 \mathrm{Mo}, 1.8 \mathrm{Be}, 3.7 \times$ \\
Rexillium III & & & \\
PARTiAL DENTURE & Ticonium & 032185 & $66 \mathrm{Ni}, 17 \mathrm{Cr}, 5 \mathrm{Mo}, \mathrm{Al}, 5 \mathrm{Mn}, 1 \mathrm{Be}, 1 \times$ \\
Ticonium 100 & Pennwalt-Jelenko & 548 & $13 \mathrm{Ni}, 27 \mathrm{Cr}, 54 \mathrm{Co}, 4 \mathrm{Mo}, 2 \times$ \\
Jelenko LG & &
\end{tabular}

*Composition determined by ESCA. 
Table 2. "Degassing" and heat treatment of porcelain-fused-to-metal alloys

Product Degassing schedule

Jelenko "O"

Cameogold

Olympia

$1300 \rightarrow 1900^{\circ} \mathrm{F}$ without vacuum, removed immediately, bench cooled

$1300 \rightarrow 1900^{\circ} \mathrm{F}$ without vacuum, removed immediately, bench cooled

$1300 \rightarrow 1900^{\circ} \mathrm{F}$ without vacuum, removed immediately, air blasted with $\mathrm{Al}_{2} \mathrm{O}_{3}$

Will Ceram Y-1 $\quad 1200 \rightarrow 1850^{\circ} \mathrm{F}$ without vacuum, held 5 min., removed and bench cooled

Will Ceram W $\quad 1200 \rightarrow 1850^{\circ} \mathrm{F}$ without vacuum, held $5 \mathrm{~min}$., removed and bench cooled

Will Ceram W-2 $1200 \rightarrow 1850^{\circ} \mathrm{F}$ without vacuum, held $5 \mathrm{~min}$., removed and bench cooled, air blasted with $\mathrm{Al}_{2} \mathrm{O}_{3}$

Litecast B $1200 \rightarrow 1850^{\circ} \mathrm{F}$ without air blasted with $\mathrm{Al}_{2} \mathrm{O}_{3}$.

PTM 88

Biobond II $1300 \rightarrow 1850^{\circ} \mathrm{F}$ without vacuum, removed and air blasted with $\mathrm{Al}_{2} \mathrm{O}_{3}$

Rexillium III $1200 \rightarrow 1740^{\circ} \mathrm{F}$ with vacuum for $10 \mathrm{~min}$

$1200 \rightarrow 1825^{\circ} \mathrm{F}$ with vacuum, color blue-gray $\rightarrow$ straw, no hold

Product

All products

above

Heat treatment schedule (to simulate firing of ceramic)

$1200 \rightarrow 1800^{\circ} \mathrm{F}$ with vacuum, no hold, cooled to room temperature in 15 min.; sequence repeated 4 times.
Mjör et al. (4) and Wennberg et al. (5) evaluated the biocompatibility of dental filling materials using cell culture techniques, implantation tests and pulp studies. They found poor correlation between these tests, thus casting doubt on the validity of using cell culture tests to evaluate cytotoxicity of dental restorative materials. The development of in vitro methods that more closely simulate the in vivo condition was advocated by Browne and Tyas (6) and suggested that cell culture tests are acceptable if the effect is local. More recently publications by Hume (7), Pahley (8) and Hanks et al. (9) have established that the design of the cell culture test is important if correlations with usage tests for dental restorative materials are to be obtained. In this regard, Pizzoferrato et al. (10) found biocompatibility testing of prosthetic implant materials by cell cultures very useful.

Stenberg (11) measured the release of cobalt from cobalt-chromium dental

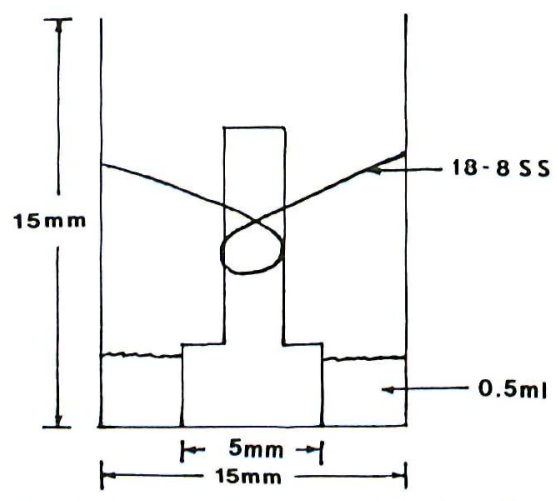

Fig. 1. Sketch of the cross section of a well in the culture dish with the alloy held in position with a stainless steel (SS) clip. alloy in human saliva and tongue scrapings. The amount in saliva varied from $200 \mathrm{ng} / \mathrm{g}$ at 2 days to $10 \mathrm{ng} / \mathrm{g}$ at 20 days. The amount of cobalt in tongue scrapings varied from about $400 \mathrm{ng} / \mathrm{g}$ at 2 days to $10 \mathrm{ng} / \mathrm{g}$ at 20 days. deMelo et al. (12) measured the release of chromium and cobalt from a partial denture in human saliva, and found more metallic $\mathrm{Cr}$ and $\mathrm{Co}$ from new than old dentures as well as a greater decrease in $\mathrm{Cr}$ than Co from new to old dentures. Covington et al. (13) measured $\mathrm{Ni}$ and $\mathrm{Be}$

Table 3. Ranking of the appearance of the Balb/c 3 T 3 cells after 24 hours on a $1-5$ scale, 1 showing good attachment and 5 indicating rounded cells

\begin{tabular}{llc}
\hline Alloy & \multicolumn{2}{c}{ Condition } \\
\cline { 2 - 3 } & As-cast & Polished \\
\hline
\end{tabular}

CASTING

Firmilay

Rajah

Midas

Forticast

Midigold

Minigold

Satincast

Albacast

MS

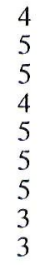

2
2
2
2
2
2
4
1
4

PORCELAIN-FUSED-TO-METAL

Jelenko "O"

Cameogold

Olympia

PTM 88

Will Ceram Y-1

Will Ceram W

Will Ceram W-2

Will Ceram Litecast B

Biobond II

Rexilium III

PARTIAL DENTURE

Ticonium 100

Jelenko LG leakage from base metal casting alloys and found high levels of Be in comparison to the concentration in the alloy and that Be was more cytotoxic than $\mathrm{Ni}$.

Wright et al. (14) determined the corrosion of Au-Cu-Ag ternary alloys by polarization and cytotoxicity using the $\mathrm{Cr}^{51}$ test and found a correlation between corrosion and the concentration of copper in the culture medium. Pourbaix (15) studied the electrochemical corrosion of silver-, gold-, and nickel-base biomaterials. Corrosion of silver- and gold-base alloys was from Ag-rich and possibly $\mathrm{Cu}$-rich segregations. Au, Pt and Pd provided anodic film protection and addition of $\mathrm{Pd}$ to $\mathrm{Ag}-\mathrm{Cu}$ greatly increased the corrosion resistance. In the Ni-base alloy $\mathrm{Mo}$, $\mathrm{Mn}, \mathrm{Co}, \mathrm{Ga}$, and above $20 \% \mathrm{Cr}$ increased the corrosion resistance.

Geis-Gerstorfer and Weber (16) found that the presence of $\mathrm{KSCN}$ in artificial saliva increased the corrosion of Ni-Cr alloys and that those containing $\mathrm{Be}$ were the worst because of lack of passivation. They considered $\mathrm{Co}-\mathrm{Cr}$ to be non-corrosive and $\mathrm{Cu}-\mathrm{Al}$ to be so easily corroded that it should not be used in dental practice. Corso et al. (17) evaluated tarnish resistance of gold-base dental alloys and found the microstructure (e.g. 2-phases) was 

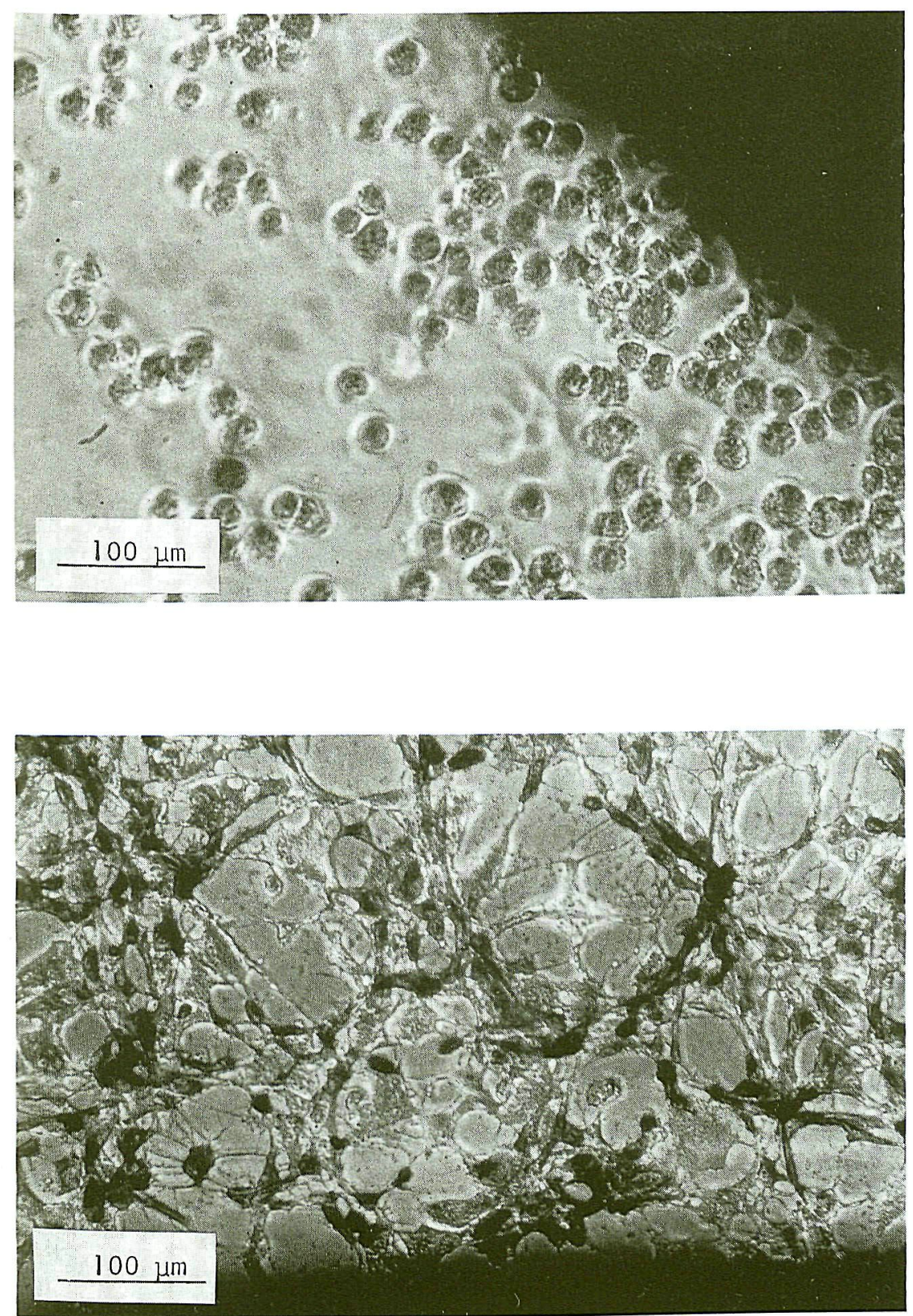

Fig. 2. Typical rounded morphology of cells after contact with an as-cast gold casting alloy (a), and after contact with a polished gold casting alloy followed by SDH staining (b).

more important than the nobility. If 2 phases exist, $\mathrm{AgCl}$ or $\mathrm{Ag}_{2} \mathrm{~S}$ are formed.

In a recent study by Zitter and Plenk (18) of Au, FeCrNiMo, CoCrWNi, Ti, and TiAlVNbTa implant alloys that electrochemical behavior was a good indicator of their biocompatibility.

\section{Material and methods \\ Preparation of samples}

The alloys, manufacturers, batch numbers, and information on compositions are listed in Table 1. Samples for cell culture testing were cast in the dimensions and shape shown in Fig. 1. The a rag wheel. The polished samples were ultrasonically cleaned for $10 \mathrm{~min}$ in Jelenko Polishing Compound Remover diluted 1:3 with distilled water and then for $10 \mathrm{~min}$ in $95 \%$ ethanol.

The porcelain-fused-to-metal alloy samples were prepared as follows. The as-cast condition was obtained by cleaning the castings by air blasting with $50 \mu \mathrm{m} \mathrm{Al} \mathrm{Al}_{3}$ followed by $50 \mu \mathrm{m}$ glass beads and by ultrasonic cleaning for $5 \mathrm{~min}$ in $95 \%$ ethanol. The samples were "degassed" and heat-treated according to the schedules listed in Table 2. These samples were then air blasted with glass beads and ultrasonically cleaned for $5 \mathrm{~min}$, in $95 \%$ ethanol. The polished samples were prepared by successively polishing the air blasted samples with an abrasive wheel, and then Tripoli and rouge on a rag wheel. The polished samples were ultrasonically cleaned for $10 \mathrm{~min}$. in Jelenko Polishing Compound Remover diluted 3:1 with distilled water and then in 95\% ethanol for $10 \mathrm{~min}$. These samples were "degassed" and heat-treated according to the schedules listed in Table 2. Following the heat treatment they were polished and cleaned as before.

Surface analysis of as-cast and polished samples were conducted using a scanning electron microscope (ESCA) in order to determine whether they were contaminated with abrasives or polishing agents. Also, the composition of the alloys not available from the manufacturers listed in Table 1 were determined by ESCA, as indicated.

\section{Cell culture testing}

Three samples of each alloy in each of the 2 conditions (as-cast and polished) were positioned in 824 -well sterile culture dishes. Each 24-well dish also contained 2 polyvinyl chloride positive controls, 2 Teflon negative controls, and 2 blanks. The samples were maintained in the center of the well with 18-8 stainless steel clips as shown in Fig. 1. The culture dishes containing the samples were sterilized using ethylene oxide for $24 \mathrm{~h}$ and were then degassed in a vacuum dessicator for one month prior to plating the cells.

$\mathrm{Balb} / \mathrm{c} 3 \mathrm{~T} 3$ cells were grown in medium containing $90 \mathrm{ml}$ Dulbecco's modified Eagle's medium, $10 \mathrm{ml}$ new calf serum, $1.25 \mathrm{ml}$ penicillin/streptomycin $(0.12 \mathrm{ml} / 10 \mathrm{ml})$, and $1 \mathrm{ml}$ glutamine $(0.1 \mathrm{ml} / 10 \mathrm{ml})$. The cells were plated at $\sim 50,000$ cells $/ \mathrm{cm}^{2}$ with $0.5 \mathrm{ml}$ placed in each well. The culture dishes were 

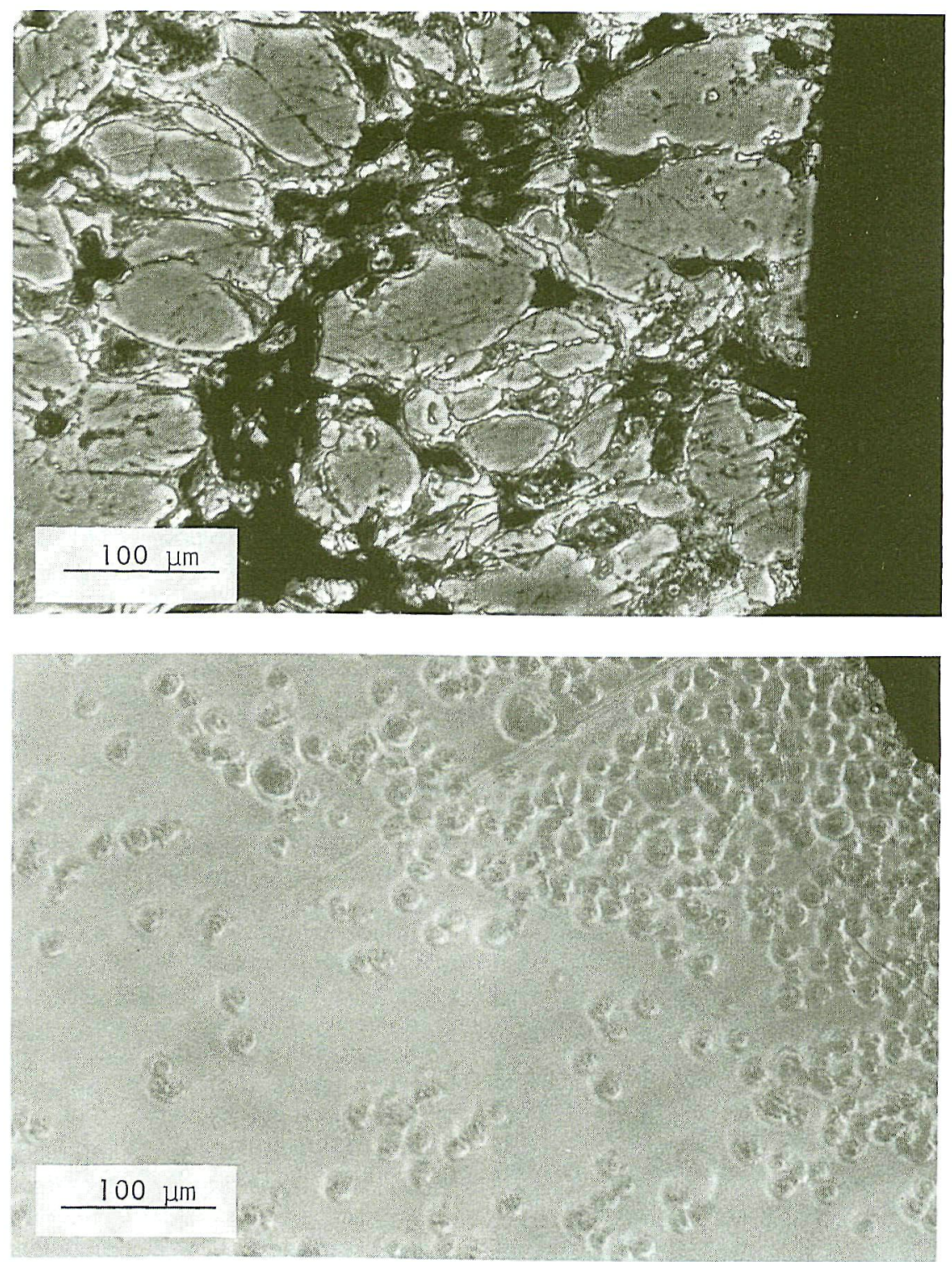

Fig. 3. Histologically stained cells in contact with the Teflon negative control (a) and morphology of cells in contact with polyvinyl chloride (PVC) positive control (b).

placed in an incubator in a humid atmosphere of $5 \% \mathrm{CO}_{2}$ and $95 \%$ air at $37^{\circ} \mathrm{C}$.

The samples were examined using phase contrast microscopy after 2 days in the culture system and the condition of the cells was ranked from 1 through 5 as follows: 1 good attachment of cells to plastic substrate around samples; 2 cells attached to substrate, but a sparse ring of cells exist adjacent to the samples; 3 loss of some cells from the substrate, with some rounded cells adjacent to samples; 4 most cells are rounded with a few attached; and 5 all remaining cells rounded, both on substrate and floating. Photographs were taken at the third day. After photographing the cells, the succinic dehydrogenase (SDH) activity was deter-

\section{Results}

The appearance of the cells $24 \mathrm{~h}$ after plating was ranked and the values for the as-cast and polished samples are listed in Table 3. Generally, substantially higher rankings, indicating more cellular interactions were obtained for the casting alloys in the as-cast compared to the polished condition except for Satincast and MS. A typical example is shown in Fig. 2a for the cellular reaction to an as-cast gold casting alloy photographed in phase contrast and before SDH staining. The rounded cells were unattached and lost during steps subsequent to phase contrast microscopy. Fig. 2 b shows the cellular reaction to a typical polished gold casting alloy after SDH staining; these cells were flat and well attached and were metabolically active. The cellular activity is shown in Figs. $3 \mathrm{a}$ and $3 \mathrm{~b}$ for the Teflon negative control and the PVC positive control. A typical example of the cellular activity in the presence of an as-cast polished metal-ceramic alloy is shown in Figs. 4a and $4 \mathrm{~b}$ after SDH staining, indicating little evidence of cytotoxicity.

Any ring of cellular inhibition determined by succinic dehydrogenase activity at 3 days was measured as the distance from the sample to the region of cellular activity. The values are listed in Table 4. Only Satincast and MS had a ring of inhibition in the polished condition, with the other casting and the partial denture alloys showing a major decrease in the width of the ring of inhibition from as-cast to the polished condition. Of particular interest is the slight or no cellular inhibition of the porcelain-fused-to-metal alloys in the as-cast condition.

The optical densities of the histochemically stained Balb/c 3T3 cells around the as-cast and polished alloys compared to the unstained center of the wells are listed in Table 5. Also listed is the difference between the optical densities of the polished minus those for the as-cast alloys. An analysis of variance at $p=0.05$ showed significant differences among alloys and between as-cast and polished samples of the same alloys. However, strong interactions were observed and thus only a t-test at $p=0.05$ was used to assess the significance of the optical densities of the cells for the individual alloys in the as-cast polished condition. The Scheffe interval for differences in optical density of cells in the presence of as-cast or 

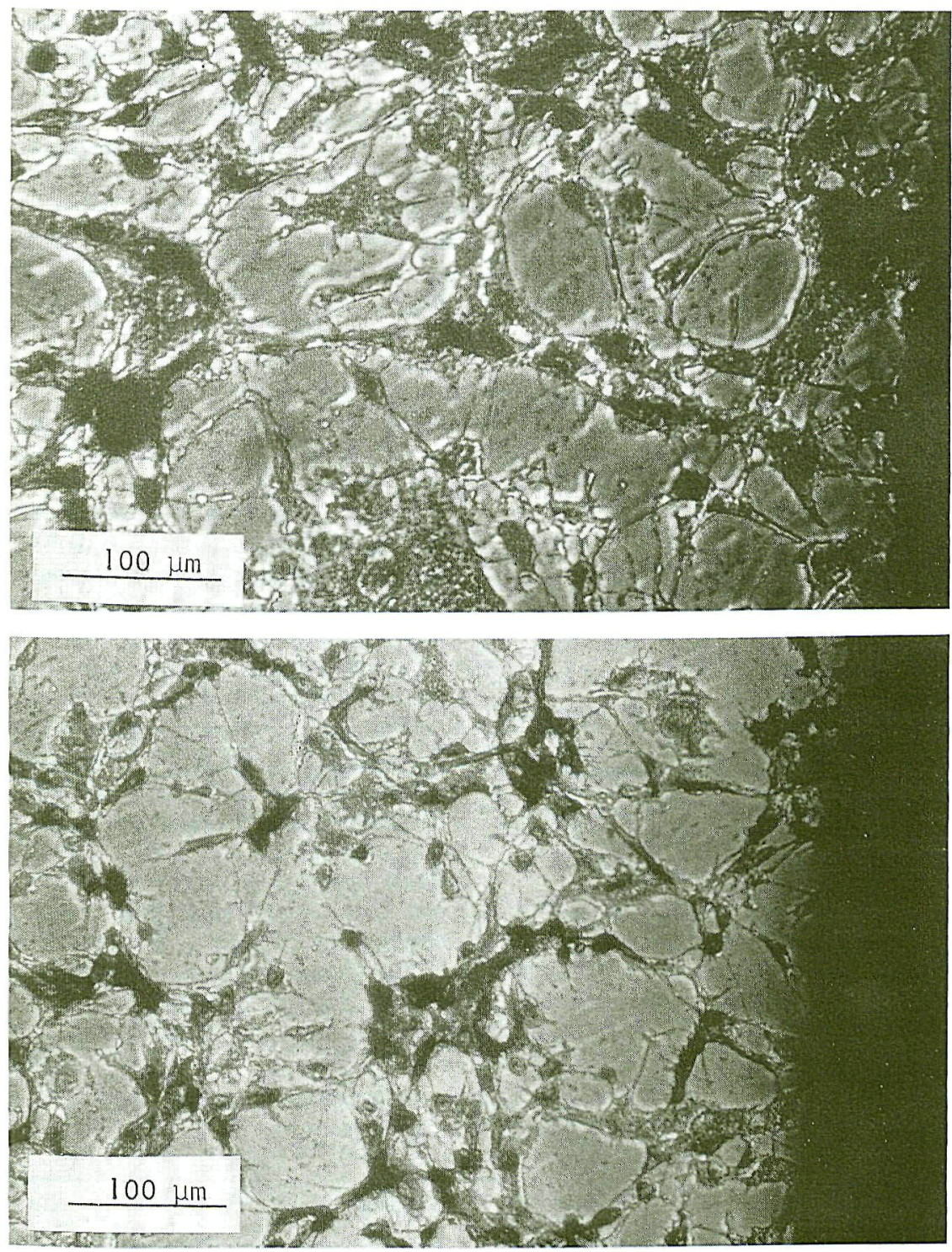

Fig. 4. Typical morphology of cells after contact with an as-cast porcelain-fused-to-metal alloy followed by SDH staining (a) and typical morphology of cells after contact with a polished procelain-fused-to-metal alloy after SDH staining (b).

polished casting alloys was 3.0 and in the presence of as-cast porcelain-fusedto-metal and partial denture alloys was 1.7 and for polished porcelain-fused-tometal and partial denture alloys was 2.5.

For the casting alloys the difference in the optical densities of the SDH reaction in the cell monolayers for the polished and as-cast condition were statistically significant for all but Satincast and Albacast. It should be pointed out that the optical densities of the SDH reacted cells for Satincast were significantly less than for Albacast. MS was unusual in that the optical densities of the SDH reacted cells were higher for the as-cast compared to the polished the optical density measurement. The optical density of the cells for the Cobase partial denture alloy, Jelenko LG, was significantly less than for the Nibase alloy, Ticonium 100 although for Jelenko LG there was no statistical difference between the optical density of cells for as-cast compared with polished while a significantly higher value resulted for polished Ticonium 100 compared with as-cast.

\section{Discussion}

The better biocompatibility of the polished casting alloys compared with the corresponding as-cast alloys may be related to the decreased dissolution of metallic elements such as copper and/or the decreased surface area in contact with the medium. This explanation is consistent with the observations of Wright et al. (14) who found a positive correlation between cytotoxicity of Au$\mathrm{Cu}-\mathrm{Ag}$ alloys and the concentration of copper in the culture medium. The explanation is also supported by a positive correlation of the interaction of Balb/c3T3 cells with a series of experimental gold alloys with increasing copper concentrations (Craig 19). The high ranking (Table 3 ) and large ring of inhibition of SDH activity (Table 4) of Satincast and MS even in the polished condition may be a result of high copper concentrations of 48 and $62 \mathrm{wt} \%$, respectively.

Of the first 6 gold casting alloys in Tables 3 and 4, Forticast had the highest copper concentration of $21.5 \mathrm{wt} \%$ although its biocompatibility was similar to the others. However, it contains the highest palladium content of the 6 alloys, $9 \mathrm{wt} \%$, and the higher palladium concentration may compensate for the higher copper concentration with respect to its biocompatibility. This suggestion is supported by Pourbaix (15) who found that palladium in gold-copper alloys increased their corrosion resistance. It should be noted that Zitter and Plenk (18) found electrochemical behavior of alloys was a good indication of their biocompatibility.

The narrow ring of cellular inhibition of Albacast casting alloy, assessed by SDH activity, is probably a result of its being a silver-palladium alloy containing no copper.

The proposal that copper may have a prominent effect on cellular inhibition is supported by the early studies of Kawahara et al. (1) who found that the 
Table 4. Width of a ring in $\mathrm{mm}$ of cellular inhibition assessed by succinic dehydrogenase activity after 3 days.

\begin{tabular}{llc}
\hline Alloy & \multicolumn{2}{c}{ Condition } \\
\cline { 2 - 3 } & As-cast & Polished \\
\hline
\end{tabular}

\section{CASTING}

\section{Firmilay}

Rajah

Midas

Forticast

Midigold

Minigold

Satincast

Albacast

MS

PORCELAIN-FUSED-TO-METAL

Jelenko "O"

Cameogold

Olympia

PTM 88

Will Ceram Y-1

Will Ceram W

Will Ceram W-2

Will Ceram Litecast B

Biobond II

Rexilium III

PARTIAL DENTURE

Ticonium 100

Jelenko LG

cytotoxicity of Group I, II and III elements was high for those of low atomic numbers which would include copper but non-existent for those of high atomic numbers as silver or gold.

ESCA analysis of the surfaces of the as-cast gold casting alloys showed traces $(<1 \%)$ of $\mathrm{Si}$ and $\mathrm{Al}$, probably as a result of residual amounts of abrasives used in the air blasting. ESCA analysis of the surfaces of the polished alloys showed no evidence of these elements. However, these elements would be present as oxides and it is unlikely they would produce the significant incompatibility of the as-cast alloys.

The small or non-existent difference in rankings of as-cast and polished porcelain-fused-to-metal alloys is probably the result of the presence of an adherent base metal oxide surface layer of the elements such as In and Sn that are present in the noble alloys to produce a bond between the alloy and the porcelain. Also, these alloys contain no $\mathrm{Cu}$ because it would cause color problems with the porcelain. The non-noble porcelain-fused-to-metal alloys as well as the partial denture alloys contain elements, notably $\mathrm{Cr}$, that form protective oxide layers and the passivation of these surfaces probably contribute to their biocompatibility.

The extent of histochemical staining

$\begin{array}{lc}4.6 & 0 \\ 5.3 & 0 \\ 4.2 & 0 \\ 2.3 & 0 \\ 1.8 & 0 \\ 2.6 & 0 \\ 5.3 & 4.5 \\ 0.5 & 0 \\ 0.5 & 1.9\end{array}$

$\begin{array}{cc}0 & 0 \\ 0 & 0 \\ 0 & 0 \\ 0.4 & 0 \\ 0 & 0 \\ 0 & 0 \\ 0 & 0 \\ 0.2 & 0 \\ 0 & 0 \\ 0 & 0\end{array}$

1.1

2.5

for succinic dehydrogenase activity determined by the ring of inhibition and optical density measurements generally confirmed the ranking data. One un-

usual observation was the narrow ring of inhibition for as-cast MS compared with the value for the polished alloy. The high concentration of $\mathrm{Al}(27 \mathrm{wt} \%)$ may have resulted in a better oxide layer in the as-cast versus the polished surface. Also, the small decrease in the ring of inhibition for polished Satincast may be the result of the high $\mathrm{Cu}$ concentration of 48 wt \% and the absence of $\mathrm{Al}$ as in MS.

The difference in the optical density of histochemically stained Balb/c 3T3 cells between polished and as-cast samples give strong support for the benefit of well polished cast gold restorations. The low optical densities of cells in contact with polished Satincast and MS suggests these alloys have some serious problems with cytotoxicity. For porcelain-fused-to-metal alloys no statistically significant difference was observed in the optical density of histochemically stained cells except for Jelenko "O" and PTM 88 where the polished condition was superior to the as-cast condition. This observation may be the result of the high noble element content and a less satisfactory oxide layer. For the partial denture alloys, polishing the Ni-base alloy improved the biocompatibility but no effect was observed for the Co-base alloy although it was less compatible than the

Table 5. Optical densities of histochemically stained Balb/c 3T3 cells around alloys

\begin{tabular}{|c|c|c|c|}
\hline \multirow[t]{2}{*}{ Alloy } & \multicolumn{3}{|c|}{ Condition } \\
\hline & As-cast & Polished & $\begin{array}{c}\text { Difference between polished } \\
\text { and As-cast }\end{array}$ \\
\hline \multicolumn{4}{|l|}{ CASTING } \\
\hline Firmilay & 8.2 & 13.0 & 4.8 \\
\hline Rajah & 5.7 & 13.6 & 7.9 \\
\hline Midas & 7.6 & 13.2 & 5.6 \\
\hline Forticast & 5.6 & 15.3 & 9.7 \\
\hline Midigold & 8.0 & 14.1 & 6.1 \\
\hline Minigold & 7.5 & 14.6 & 7.1 \\
\hline Satincast & 7.9 & 8.5 & $0.6^{*}$ \\
\hline Albacast & 16.6 & 16.2 & $-0.4^{*}$ \\
\hline MS & 13.5 & 8.9 & -4.6 \\
\hline \multicolumn{4}{|c|}{ PORCELAIN-FUSED-TO-METAL } \\
\hline Jelenko "O" & 12.3 & 14.9 & 2.6 \\
\hline Cameogold & 14.3 & 13.8 & $-0.5^{*}$ \\
\hline Olympia & 15.2 & 16.3 & $1.1^{*}$ \\
\hline PTM 88 & 11.9 & 16.8 & 4.9 \\
\hline Will Ceram Y-1 & 13.8 & 14.6 & $0.8^{*}$ \\
\hline Will Ceram W & 15.7 & 15.0 & $-0.7^{*}$ \\
\hline Will Ceram W-2 & 13.3 & 17.8 & $4.5^{*}$ \\
\hline Will Ceram Litecast B & 13.8 & 16.0 & $2.2^{*}$ \\
\hline Biobond II & 14.4 & 16.1 & $1.7^{*}$ \\
\hline Rexillium III & 16.3 & 15.9 & $-0.4^{*}$ \\
\hline \multicolumn{4}{|l|}{ PARTICAL DENTURE } \\
\hline Ticonium 100 & 11.1 & 16.4 & 5.3 \\
\hline Jelenko LG & 8.3 & 9.9 & $1.6^{*}$ \\
\hline
\end{tabular}

*Not significant at $\mathrm{p}=0.05$. 
Ni-base alloy at comparable conditions. No reasonable explanation can be offered for this difference.

The evaluations of biocompatibility of dental casting alloys using cell culture tests appear valid in spite of criticism by Mjör et al. (4) and Wennberg et al. (5). What appears to be important is that the cell culture test must reasonably simulate usage conditions. Much of the criticism of cell culture tests has resulted from attempts to correlate dental pulpal studies (usage tests) on restorative materials with direct contact cell culture tests. However, Hume (7), Pashley (8) and Hanks et al. (9) have shown that dentin serves as a barrier to components of restorative material reaching the pulp. This dentin barrier causes a dispersion gradient which reduces the effects of toxic materials in the cavity preparation and results in poor correlation between these pulp studies and direct contact cell culture tests. However, dental casting alloys are in direct contact with some oral tissues, and evaluation of their biocompatibility by a cell culture test where they are in direct contact with the medium is acceptable.

Explanations of the differences in biocompatibility of these alloys are, however, somewhat speculative at present. Additional surface analysis and atomic absorption measurements on cell culture medium that had been in contact with alloys is underway in an attempt to correlate biocompatibility with composition.

\section{References}

1. Kawahara $\mathrm{H}$, Yamagami $\mathrm{A}$, Nakamura M. Biological testing of dental materials by means of tissue culture. Internat Dent J 1968: 18: 443.

2. Bergman $M$, Ginstrup O. Dissolution rate of cadmium from dental gold solder alloys. Acta Odontol Scand 1975: 33: 199.

3. Bergman B, Bergman M, Soremark R. Dissolution and uptake of cadmium from dental gold solder alloy implants. Scand J Dent Res 1977: 85: 623.

4. Mjör IA, Hensten-Pettersen A, Skoegedal $\mathrm{O}$. Biologic evaluation of filling materials. A comparison of results using cell culture techniques, implantation tests and pulp studies. Internat Dent J 1977: 27: 124.

5. Wennberg A, Mjör IA, Hensten-Pettersen A. Biological evaluation of dental restorative materials - a comparison of different test methods. J Biomed Mater Res 1983: 17: 23.

6. Browne RM, Tyas MJ. Biological testing of dental restorative materials in vitro - a review. J Oral Rehabil 1979: 6: 365.

7. Hume WR. A new technique for screening chemical toxicity to the pulp from dental restorative materials and procedures. J Dent Res 1985: 64: 1322.

8. Pashley DH. Dentin-predentin complex and its permeability: physiologic overview. J Dent Res 1979: 64(Special Issue): 613.

9. Hanks CT, Craig RG, Syed SA, Adams ER. Dentin filtration reduces cytotoxic effects of setting composites in vitro. J Dent Res 1987: 66(Special Issue): 287.

10. Pizzoferrato A, Vespucci A, Ciapetti G, Stea S. Biocompatibility testing of prosthetic implant materials by cell cultures. Biomater 1985: 6: 346.

11. Stenberg T. Release of cobalt from cobalt chromium alloy constructions in the oral cavity of man. Scand J Dent Res 1982: 90: 472 .

12. deMelo JF, Gjerdet NR, Erichsen ES. Metal release from cobalt-chromium partial dentures in the mouth. Acta Odontol Scand 1983: 41: 71.

13. Covington JS, McBride MA, Slagle WF, Disney AL. Quantization of nickel and beryllium leakage from base metal casting alloys. J Prosthet Dent 1985: 54: 127.

14. Wright DC, Gallant RF, Spangberg L. Correlation of corrosion behavior and cytotoxicity in $\mathrm{Au}-\mathrm{Cu}-\mathrm{Ag}$ ternary alloys. J Biomed Mater Res 1982: 16: 509.

15. Pourbaix M. Electrochemical corrosion of metallic biomaterials. Biomater 1984: 5: 122.

16. Geis-Gerstorfer J, Weber H. Der einfluss von kalium-rhodanid auf das korrosionsverhalten edelmetallfreier dentallegierungen. Deut Zahnaerzt Zeit 1985: 40: 87 .

17. Carso Jr PP, German RM, Simmons Jr HD. Tarnish evaluation of gold-based dental alloys. J Dent Res 1985: 64: 848 .

18. Zitter H, Plenk Jr H. The electrochemical behavior of metallic implant materials as an indicator of their biocompatibility. J Biomed Mater Res 1987: 21: 881.

19. Craig RG. Unpublished data 1987. 
This document is a scanned copy of a printed document. No warranty is given about the accuracy of the copy. Users should refer to the original published version of the material. 